\title{
KOSZORÚÉRSZTENTEK OLDALÁGELÉRÉSI LEHETŐSÉGÉNEK ELŐREJELZÉSE
}

\section{PREDICTION OF SIDE BRANCH ACCESS POSSIBILITY OF CORONARY ARTERY STENTS}

\author{
Károly Dóra ${ }^{1}$, Károly Péter Balázs ${ }^{2}$ \\ Budapesti Müszaki és Gazdaságtudományi Egyetem, Gépészmérnöki Kar, \\ Anyagtudomány és Technológia Tanszék, Cím: 1111 Magyarország, Budapest, \\ Bertalan Lajos u. 7. Telefon: +061-463-1114 \\ Ikdora@eik.bme.hu, ${ }^{2}$ peti.karoly@gmail.com
}

\begin{abstract}
In the case of bifurcation lesions stent implantation is required in the main and side branch vessel. The physicians use different techniques, but all based on the dilation of one central cell of the stent. This work deals with the investigation and prediction of side branch access property among the functional properties of coronary stents. With the results, one can specify whether a stent is suitable for bifurcation stenting and if so, what is the maximum reachable diameter of the cell.
\end{abstract}

Keywords: coronary artery stent, functional property, side branch access

\section{Összefoglalás}

Bifurkációs léziók esetén szükség lehet a fö és mellék érágba is sztentet implantálni. Ezt az orvosok különböző technikákkal teszik meg, viszont mindegyik a sztent egyik középső cellájának tágításán alapul. Jelen munka a sztentek funkcionális tulajdonságai közül az oldalágelérés vizsgálatával és előrejelzésének lehetőségeivel foglalkozik. Az eredmények birtokában megadható, hogy egy adott sztent alkalmas-e oldalági tágításra és amennyiben igen, mekkora az elérhető maximális cellaátmérö.

Kulcsszavak: koszorúérsztent, funkcionális tulajdonság, oldalágelérés.

\section{Bevezetés}

A koszorúérbetegség egyik legelterjedtebb kezelési módszere a sztentbeültetés. A sztent egy kisméretü általában biokompatibilis anyagú csőből kivágott hálós szerkezet, amelyet ballonkatéterre szerelve az ér szükült területére juttatnak. A sztentelés egy speciális, de mégis gyakran alkalmazott módszere a bifurkációs sztentelés (1. ábra). Az elfogadott definíció szerint a bifurkációs lézió olyan koszoruér szükület, amely a fö érágba és/vagy a mellék érágba is kiterjed. Egyes források szerint ezek az elváltozások az összes sztentelés közel 15-20\%-át adják, így az elágazó ereknél alkalmazott sztentelések vizsgálata kiemelkedően fontos [1].

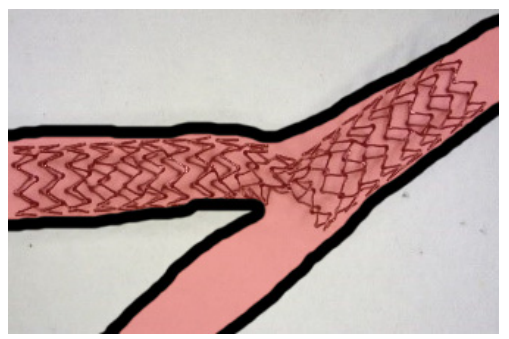

1. ábra. Oldalágelérés (sztent-ballon technika) 
A koszorúér bifurkációkat a fó érág és a mellék érág közti szög és a plakk helyzete alapján osztályozzák. A fóág és oldalág helyzeténél kiemelt szerepet kap a $70^{\circ}$-os szög, a plakk helyzete alapján pedig hat fö csoportosítási rendszert különböztetünk meg. A mellék érág nyílásához közeli plakk több komplikációt jelent és nagyobb valószínüséggel lépnek fel problémák a sztentelés után is $[2,3]$.

A kezelési módokat hat csoportra oszthatjuk [1]. Az oldalágelérés előrejelzése szempontjából nem számít, hogy milyen sorrendben lettek bevezetve a szentek, vagy feltágítva a ballonok, amelyet az orvosok külön technikának minősítenek. Számunkra a feltágított cella helyzete érdekes (tehát, hogy a sztent közepén vagy szélén található-e a cella), így nem foglalkozunk az egyes módszerek külön bemutatásával.

A piacon már megjelentek az úgynevezett dedikált bifurkációs sztentek, melyeket kifejezetten az elágazó erek sztentelésére gyártanak. A különböző gyártók által készített sztentek teljesen eltérőek, emiatt tulajdonságaik szinte összehasonlíthatatlanok. Engedélyeztetésüknél problémát okoz, hogy újra végig kell csinálni a klinikai teszteket minden egyes új geometria esetén, mivel nagy eltérések vannak a különböző kialakítások alkalmazása során. Emiatt és a technológia kifejlesztési költségei miatt az eszközök igen drágák. A bifurkációs elváltozások anatómiája minden egyes betegnél nagyon eltérő, így ezek a dedikált sztentek nem alkalmazhatóak minden páciensnél [4]. Mindezek miatt az orvosok nagy számban „sima” egyenes érágba tervezett és gyártott sztenteket használnak a bifurkációs léziók kezelésére.

A szakirodalomban csak kevés oldalágelérésre vonatkozó müszaki vizsgálat található. A legtöbb cikk orvosi szempontból írja le magát a sztentelési technikát, vagy a sztentelés utáni komplikációkat. $\mathrm{Az}$ oldalági tágítást müszaki szempontból vizsgáló cikkek számítógépes szimulációval modellezik a problémát, de elörejelzést és valós vizsgálatokat nem végeznek. Az MSZ EN ISO 25539-2 jelü sztentekre vonatkozó szabványban sem szerepel az oldalágelérés tulajdonság leírása [5].

Oldalági tágítás előtt a sztentmintázat leképezése után a cellaméretek segítségével elörejelzést adhatunk arról, hogy az adott sztent egyáltalán alkalmas-e az oldalágelérésre.

\section{Eszközök és módszerek}

A kutatás során felhasznált sztentek névleges adatai az 1. táblázatban láthatók.

1. táblázat. Felhasznált sztentek adatai

\begin{tabular}{|c|c|c|c|c|}
\hline $\begin{array}{c}\text { Sztent } \\
\text { típusa }\end{array}$ & $\begin{array}{c}\text { Névl. } \\
\text { átmérō } \\
\text { (mm) }\end{array}$ & $\begin{array}{c}\text { Névl. } \\
\text { hossz } \\
\mathbf{( m m )}\end{array}$ & $\begin{array}{c}\text { Alap- } \\
\text { anyag }\end{array}$ & $\begin{array}{c}\text { Névl. } \\
\text { Nyo- } \\
\text { más } \\
\text { (bar) }\end{array}$ \\
\hline $\begin{array}{c}\text { Boston, } \\
\text { Promus }\end{array}$ & 3,00 & 12 & $\mathrm{CoCr}$ & 8 \\
\hline $\begin{array}{c}\text { Medtronic, } \\
\text { Integrity }\end{array}$ & 3,00 & 12 & $\mathrm{CoCr}$ & 11 \\
\hline $\begin{array}{c}\text { Boston, } \\
\text { Promus } \\
\text { element }\end{array}$ & 2,25 & 16 & $\mathrm{PtCr}$ & 12 \\
\hline $\begin{array}{c}\text { Meril, } \\
\text { Nexgen }\end{array}$ & 3,00 & 24 & $\mathrm{CoCr}$ & 9 \\
\hline $\begin{array}{c}\text { Eurocor, } \\
\text { Genius Magic }\end{array}$ & 4,00 & 13 & $\mathrm{CoCr}$ & 6 \\
\hline
\end{tabular}

A sztentekről a névleges nyomásra való tágítás után sztentmintázat leképezésére alkalmas berendezéssel elkészítettük a palástterítékeket [6]. A vizsgált sztentek mintázata három csoportra osztható. Homogén mintázatúnak nevezhetőek azok, amelyeknél a sztent teljes felülete közel azonos mintaelemekből áll, ilyen az Integrity sztent. Ismétlődő gyürüs mintázatúnak nevezhetőek azok a kialakítások, ahol a bordákból álló gyürüket a sztent hosszirányában hidak kötik össze, ilyenek a Promus és Promus element sztentek. Illetve kevert mintázatúak, amikor a sztent szélein levő cellák eltérőek a sztent 
belső részén található celláktól, mind méretben, mind kialakításban, ilyenek a Nexgen és Genius Magic sztentek.

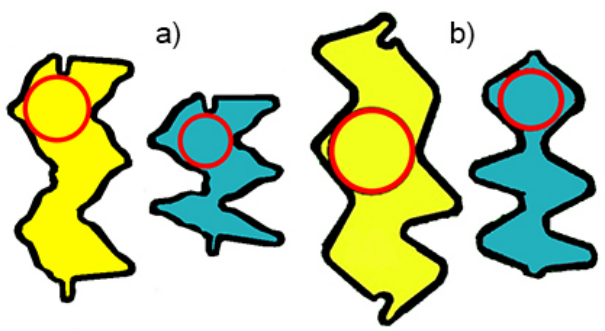

2. ábra. a) Promus és b) Genius Magic sztent legnagyobb és legkisebb cellája

A sztentmintázat alapján a következő adatokat számítottuk ki, illetve mértünk le a JMicroVision program segítségével: cellaterületek, cellakerületek, beírható legnagyobb körök átmérője és területe, tágítható legnagyobb körök átméröje és területe (2. ábra). A tágítható legnagyobb körök átméröjét a cellakerület alapján határoztuk meg, a cellakerületet vettük a kör kerületének. A Nexgen sztent esetén a külső cellák mérete jóval kisebb volt, mint a belső celláké (3. ábra), ahol a tényleges oldalági tágítást végzik az orvosok, így a Nexgen korrigált értékek a külső cellákat nem veszik figyelembe.

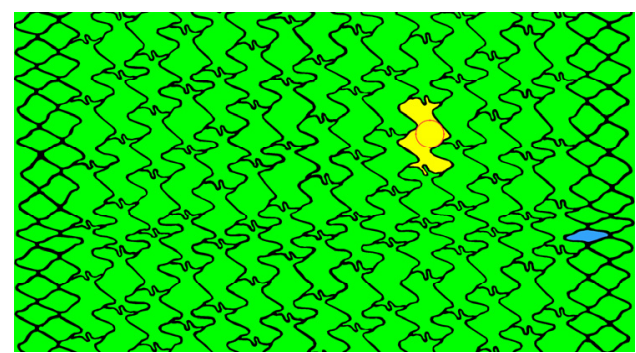

3. ábra. Nexgen sztent palástteritéke

\section{Eredmények}

$\mathrm{Az}$ ábrákon zölddel vannak jelölve az átlagos értékek, sárgával a legnagyobb, kékkel pedig a legkisebb méretek. A 4. ábrán látszik, hogy a különböző sztentmintázatok mennyire eltérő cellaterületeket eredményeznek.

Cellaterület

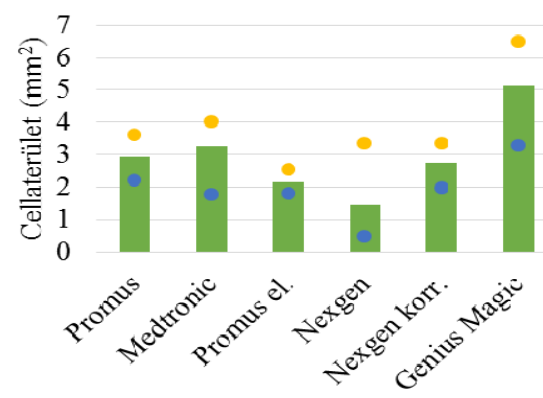

\section{4. ábra. Cellaterületek}

A sztentek tágítás elötti profilátméröje általában $1 \mathrm{~mm}$. A cellákba beírható körök modellezik a ballonkatétert vagy sztentet, amellyel oldalági tágításkor átjutnak az adott cellán. $\mathrm{Az}$ 5. ábrán látható, hogy csupán egy sztent esetén nagyobb a legkisebb beírható körátmérö, mint $1 \mathrm{~mm}$, így mondhatjuk, hogy a sztent deformációja még az oldalági tágítás előtt, a katéter átjuttatásakor megtörténik.

\section{Beírható kör méretek}

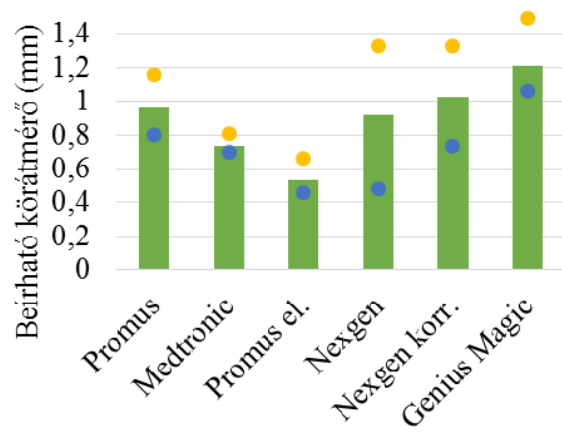

5. ábra. Beirható körátmérö értékek

A tágítható kör méretei az oldalági tágítás során elérhető legnagyobb cellaátmérőt modellezik. Ha valóban ekkorára tágítanánk a cellát, akkor a körülötte levő bordák valószínüleg eltörnének, így ez csak elméleti határ. A 
6. ábrán láthatjuk, hogy a legkisebb tágítható körátmérö minden sztentnél közel azonos (3,5-4mm). Itt jól kiemelkedik, miért van szükség a Nexgen sztent esetén korrigált értékeket használni.

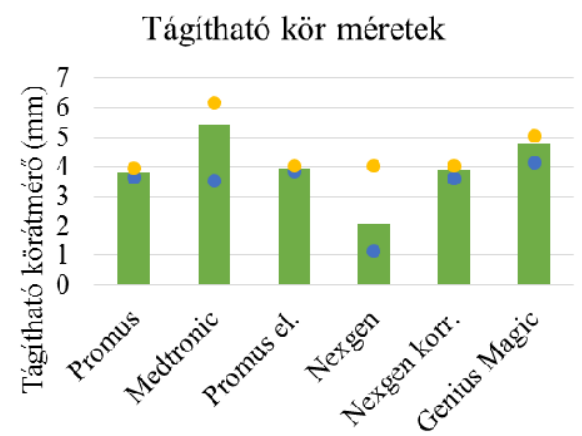

6. ábra. Tágitható körátmérő értékek

A cellaméretek alapján meghatározhatjuk azt a maximális sztent- (vagy ballon) átmérőt, amelyet még alkalmazhatnak az orvosok a sztent nagyfokú deformációja és a bordák törése nélkül oldalági tágításra az általunk vizsgált sztentek esetén. A 2. táblázatban láthatók azok a maximális átmérők, amelyek a Magyarországon forgalomban levő sztent és ballonméretekkel egyeztetve lettek megadva.

2. táblázat. Tágitható körátmérö és alkalmazható maximális átmérö értékek

\begin{tabular}{|c|c|c|}
\hline $\begin{array}{c}\text { Sztent } \\
\text { típusa }\end{array}$ & $\begin{array}{c}\text { Átl. tágítható } \\
\text { körátmérö } \\
(\mathbf{m m})\end{array}$ & $\begin{array}{c}\text { Max. sztent- } \\
\text { átmérö } \\
(\mathbf{m m})\end{array}$ \\
\hline Promus & 3,79 & 3,50 \\
\hline Medtronic & 5,42 & 5,00 \\
\hline $\begin{array}{c}\text { Promus } \\
\text { el. }\end{array}$ & 3,96 & 3,50 \\
\hline Nexgen & 2,09 & 1,50 \\
\hline $\begin{array}{c}\text { Nexgen } \\
\text { korr. }\end{array}$ & 3,89 & 3,50 \\
\hline $\begin{array}{c}\text { Genius } \\
\text { Magic }\end{array}$ & 4,78 & 4,50 \\
\hline
\end{tabular}

\section{Következtetések}

A bifurkációs léziók kihívást jelentenek a sztentelés során, mégis kevés kutatás foglalkozik az oldalági tágított sztentek in vitro vizsgálatával. Van endovaszkuláris eszközökre vonatkozó szabvány, de abban nem szerepel az oldalágelérés, mint sztenttulajdonság. Léteznek dedikált bifurkációs sztentek, de emellett az orvosok különböző módszerekkel „sima” koszorúérsztenteket is használnak az elágazások kezelésére. Az oldalági tágítás során a hagyományos sztentek nagy alakváltozáson esnek át, amely nem megfelelő méretü oldalágba felvezetett sztent vagy ballon esetén akkora lehet, hogy a sztent oldalági tágítás után nem képes betölteni a neki szánt funkciót. A cikkben bemutatott egyszerü módszer segítségével meghatározható, hogy az adott sztent cellái mekkora ármérőre tágíthatók károsodás nélkül.

\section{Szakirodalmi hivatkozások}

[1] V. H. Chen, S. K. Sharma: Science Innovation Synergy: SIS Yearbook 2006, Ch 3 Bifurcation Stenting. SIS 2006 Conference.

[2] R. Waksman, J. A. Ormiston. Essentials of bifurcation stenting. Ch 1 Classification of Coronary Artery Bifurcation Lesions. Wiley \& Blackwell, 2012.

[3] M. R. Mohaved, et al: Coronary artery bifurcation lesions: a review and update on classification and interventional techniques. Cardiovascular Revascularization Medicine 2008:9:263-268.

[4] A. A. Pillai, B Jayaraman: Dedicated bifurcation stents. Indian Heart Journal 2012:6402:187-195.

[5] MSZ EN ISO 25539-2:2012 Sziv- és érrendszeri implantátumok. Endovaszkuláris eszközök 2. rész: Vaszkuláris sztentek.

[6] M. Kovács, D. Károly, L. Dévényi: Comparing two examination methods for measuring metal to artery ratio of coronary stents. Materials Science Forum 2015:812:113-118. 